\section{Nauplius}

The Journal of The Brazilian Crustacean Society

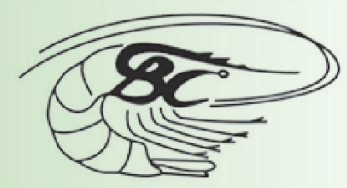

e-ISSN 2358-2936 www.scielo.br/nau www.crustacea.org.br
This article is part of the tribute offered by the Brazilian Crustacean Society in memoriam of Michael Türkay for his outstanding contribution to Carcinology

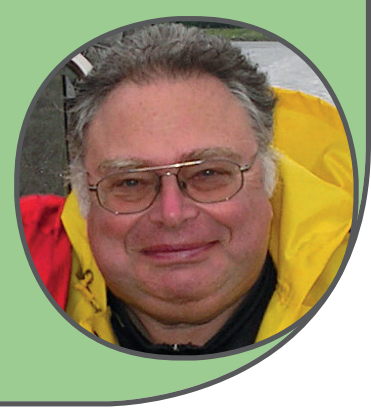

Original Article

\title{
Sundathelphusa tuerkayi, a new species of gecarcinucid freshwater crab (Crustacea: Brachyura) from Lombok Island, Indonesia
}

\author{
Peter K. L. $\mathrm{Ng}^{1}$ and Arthur Anker ${ }^{2}$
}

1 Lee Kong Chian Natural History Museum, Faculty of Science, National University of Singapore, 2 Conservatory Drive, Singapore 117377, Republic of Singapore. PKLN E-mail: peterng@nus.edu.sg
2 Programa de Capacitação Institucional, Museu Paraense Emílio Goeldi, Campus de Pesquisa. Avenida Perimetral, 1901, Terra Firme. 66077-830 Belém, Pará, Brazil. AA E-mail: arthuranker7@yahoo.com

ZOOBANK http://zoobank.org/urn:lsid:zoobank.org:pub:FD4CC845-78D2-497A8BD8-569F73910201

\section{ABSTRACT}

A new species of the freshwater crab genus Sundathelphusa Bott, 1969 is described from the Indonesian island of Lombok. Sundathelphusa tuerkayi, new species, appears to be most closely related to Sundathelphusa aruana (Roux, 1911), which is known for certain only from the Aru Islands, but differs from it and all other congeners by a unique combination of morphological characters. The new crab hosts a small ectosymbiotic temnocephalid flatworm, possibly belonging to the genus Temnosewellia Damborenea and Cannon, 2001 (Platyhelminthes: Temnocephalida).

CORRESPONDING AUTHOR

\section{Peter K. L. Ng}

peterng@nus.edu.sg

SUBMITTED 8 July 2016

ACCEPTED 19 October 2016

PUBLISHED 8 December 2016

Guest Editor

Célio Magalhães

DOI 10.1590/2358-2936e2016026

\section{KEY WORDS}

Crabs, Gecarcinucidae, South-East Asia, temnocephalid worm, symbiosis. 


\section{INTRODUCTION}

The Indonesian island of Lombok is inhabited by three known species of true freshwater crabs, all belonging to the family Gecarcinucidae: Sundathelphusa aruana (Roux, 1911), Parathelphusa lombokensis Bott, 1970, and Parathelphusa quadrata Ng, 1997 (Bott, 1970; $\mathrm{Ng}, 1997$ ), the latter two species being endemic to the island. Sundathelphusa aruana, first described from the Aru Islands to the west of West Papua, was first reported from Lombok by Bott (1970).

A re-examination of Bott's (1970) specimens from Lombok, as well as fresh material collected in 2014, leads the authors to conclude that the taxon reported as "Sundathelphusa aruana" actually represents a different species, here recognised as new to science. The description of this new species and comparisons with its closest congener $S$. aruana form the basis of the present paper.

\section{Material and Methods}

The material examined is deposited in the Naturhistorisches Museum Basel, Basel, Switzerland (NMB); Senckenberg Naturmuseum, Frankfurt-amMain, Germany (SMF); and Zoological Reference Collection of the Lee Kong Chian Natural History Museum, National University of Singapore, Singapore (ZRC). Measurements, in $\mathrm{mm}$, are provided only for adult crabs and are of the maximum carapace width and length, respectively. The terminology used follows that of $\mathrm{Ng}(1988)$.

\section{TAXONOMY}

\section{Family Gecarcinucidae Rathbun, 1904}

\section{Genus Sundathelphusa Bott, 1969}

\section{Sundathelphusa tuerkayi, new species}

(Figs. 1, 2A, 3-5)

Sundathelphusa aruana - Bott, 1970: 75 (part) (not Potamon (Geotelphusa) aruanus Roux, 1911)

Material examined. Indonesia, Nusa Tenggara Barat, Lombok Island. Holotype: male $(34.7 \times 26.5 \mathrm{~mm})$ (SMF 1799a), Sembalun, 1185 m, coll. J. Elbert, 7
March 1909-18 May 1910. Paratypes: 3 males (28.5 X $21.7 \mathrm{~mm}, 29.3 \times 22.6 \mathrm{~mm}, 30.3 \times 23.6 \mathrm{~mm}$ ), 3 females $(22.7 \times 18.2 \mathrm{~mm}, 26.3 \times 20.9 \mathrm{~mm}, 32.4 \times 25.0 \mathrm{~mm}) 1$ juvenile female $(19.5 \times 15.4 \mathrm{~mm})$ (SMF 1799b), same data as holotype; 1 male $(23.1 \times 17.8 \mathrm{~mm}), 1$ female $(38.0 \times 29.4 \mathrm{~mm})($ SMF 1800), Praya, $680 \mathrm{~m}$ above sea level, same data as holotype; 2 males $(12.7 \times 10.1 \mathrm{~mm}$, $25.4 \times 20.5 \mathrm{~mm})($ ZRC 2014.0849), 1 female $(29.0 \times$ $23.0 \mathrm{~mm})$ (ZRC 2014.0850), 1 female $(25.1 \times 20.2$ $\mathrm{mm}$ ) (ZRC 2014.0851), 1 juvenile male, 1 juvenile female (ZRC 2014.0852), 1 female $(26.6 \times 22.2 \mathrm{~mm})$ (ZRC 2014.0853), 1 male $(24.0 \times 18.9 \mathrm{~mm})$ (ZRC 2014.0854), north of Suranadi, Sesaot village, $\sim 500$ $\mathrm{m}$ above sea level, small stream, under vegetation near stream bank, coll. F. Muhammad, L.S. Pratama and A. Anker, 17 May 2014; 1 juvenile male, 1 male (17.3 × $14.0 \mathrm{~mm}$ ), 3 young females (largest $12.8 \times 10.4 \mathrm{~mm}$ ) (ZRC 2014.0855), Lombok Barat, $200 \mathrm{~m}$ above sea level, pool near small waterfall, coll. D.L. Rahayu and A. Anker, 17 May 2014.

Comparative material. Sundathelphusa aruana (Roux, 1911): paralectotype male $(27.9 \times 21.5 \mathrm{~mm})$ (NMB 695a), Indonesia, West Papua, Aru Islands, Kobroor, Manumbai.

Diagnosis. Carapace transversely ovate, inflated (Figs. 1A, C, 2A, 3A); antero- and posterolateral regions covered with distinct short, oblique striae (Figs. 1A, 2A); epigastric cristae raised, rounded, not sharp; postorbital cristae rounded, posterior to epigastric cristae (Figs. 1A, 2A); external orbital tooth low, broadly triangular, outer margin almost straight, ca. three times longer than inner margin (Figs. 1A, 2A); epibranchial tooth very low (Figs. 1A, 2A); ambulatory legs moderately long and slender (Fig. 1A); G1 terminal segment straight, subconical, tapering to subtruncate tip, outer margin lined with setae (Fig. 4A-C).

Description of male holotype. Carapace transversely ovate, inflated, broader than long, widest at anterior half, dorsal surface distinctly convex longitudinally and transversely, smooth or with scattered pits, regions visible; antero- and posterolateral regions covered with distinct short oblique striae; cervical groove shallow but prominent; $\mathrm{H}$-shaped gastric groove deep (Figs. 1A, 2A). Epigastric cristae distinct, raised, rounded, 


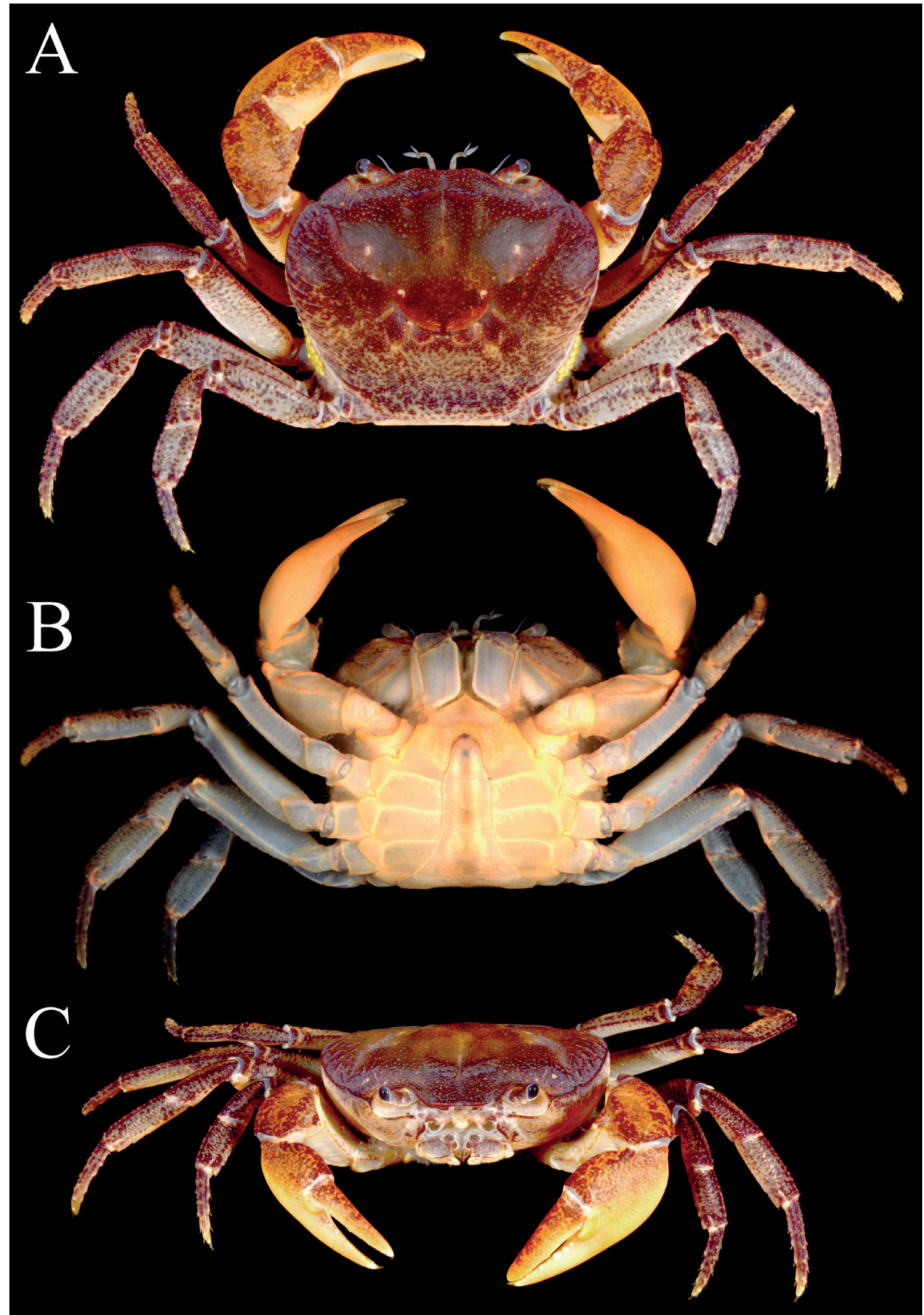

Figure 1. Sundathelphusa tuerkayi, new species, colour in life, paratype, male $(24.0 \times 18.9 \mathrm{~mm})$ (ZRC 2014.0854), Lombok, Indonesia. A, dorsal view (note bright yellow-greenish eggs of symbiotic temnocephalid flatworm on left and right branchiostegia, see also Fig. 6); B, ventral view; C, frontal view. 
separated by distinct median furrow; postorbital cristae distinct but rounded, posterior to epigastric cristae, gradually joining anterolateral margin (Figs. 1A, 2A, $3 A)$. Front relatively short, margin sinuous, deflexed, divided into two low rounded lobes (Figs. 2A, 3A). External orbital tooth low, broadly triangular, tip reaching level of frontal margin; outer margin almost straight, about three times longer than inner margin; epibranchial tooth low, separated from external orbital tooth by shallow $U$-shaped notch; anterolateral margin strongly convex, cristate, surface with low striae; posterolateral margin convex, surface with oblique striae, converging towards gently convex posterior margin of carapace (Figs. 1A, 2A). Frontal median triangle incomplete, lateral margins cristate, dorsal margin low, not confluent with lateral margins; orbit ovate, large; supraorbital margin smooth, confluent with frontal margin; infraorbital margin concave, cristate; suborbital region almost smooth; sub-branchial and pterygostomial regions almost smooth, covered with scattered low striae (Figs. 1A, C, 2A, 3A, C). Posterior margin of epistome with prominent triangular median lobe; lateral lobes low, margins sinuous (Fig. 3A). Eyes well developed, cornea pigmented, occupying almost entire orbit (Figs. 2A, 3A).

Ischium of third maxilliped relatively long, rectangular, much longer than broad, with distinct oblique submedian sulcus, surfaces pitted; merus quadrate, antero-external angle rounded; tip of exopod reaching midpoint of outer margin of merus, with long flagellum (Fig. 3D).

Chelipeds asymmetrical, not noticeably elongated; basis-ischium with low tubercle; merus margins with low uneven granules, dorsal margin with very low rounded subdistal tooth; carpus armed with strong tooth on inner distal angle, with several low tubercles basally (Figs. 2A, 3C). Major chela swollen, surfaces pitted; fingers longer than palm, strongly curved, widely gaping when closed; cutting edges weakly dentate (Figs. 2A, 3C). Minor chela with surfaces pitted, slender; fingers almost straight, distinctly longer than palm; cutting edges with numerous low teeth (Fig. 3C).

Ambulatory legs moderately long, slender; second leg longest; surfaces of articles pitted; dorsal margins of meri subcristate, uneven, weakly serrate, without subdistal tooth or spine, posterior margins smooth; carpus and propodus with dorsal margins uneven to weakly serrate; outer surface of propodus with low subdorsal ridge; dactylus quadrate in cross-section, margins lined with strong pectinate spines (Figs. 2A, 3F).

Thoracic sternum relatively broad; surfaces distinctly pitted; sternites 1-3 completely fused, sternites 2 and 3 separated by short low, median ridge; sternites 3 and 4 separated by deep transverse groove becoming obscure laterally (Fig. 3B). Sternoabdominal cavity reaching to level of anterior margin of cheliped coxae, anterior to suture between thoracic sternites 3 and 4 (Fig. 3B). Male abdominal locking tubercle large, rounded, positioned on anterior third of sternite 5 .

Male abdomen broadly T-shaped; somite 1 short, very broad, reaching to coxae of fourth ambulatory legs; somite 2 broad, transversely subrectangular; somites 3-5 trapezoidal, progressively narrower; somite 6 subquadrate, longer than broad, with concave lateral margins; telson triangular (Fig. 3B, E).

G1 moderately stout, subterminal segment gradually tapering towards terminal segment, separated from latter by distinct suture; terminal segment straight, subconical, tapering to subtruncate tip, outer margin lined with setae (Fig. 4A-C). G2 longer than G1; flagellum long, about three-quarters length of basal segment (Fig. 4D).

Female. Female chelipeds subequal, not inflated; abdomen rounded, covering entire thoracic sternum, somites and telson freely articulating. Vulvae large, round, on submedian part of somite 6; without distinct operculum (Fig. 5).

Variation. The carapaces of smaller specimens tend to be less inflated, with the branchial regions less swollen (Fig. 1A, C). Large male and female specimens have these regions prominently swollen (Figs. 2A, 3A). The chelipeds of large males also have more inflated chelae with long curved fingers that gape even when closed (Fig. 3C). Smaller males have smaller chelae with straighter fingers (Fig. 1C). The lateral margins of male abdominal somite 6 also varies, with those of large males distinctly concave (Fig. 3E), versus almost straight in smaller males (Fig. 1B).

Colour in life. Dorsal surface of carapace is reddishbrown, colour on anterior half more uniform, that on 


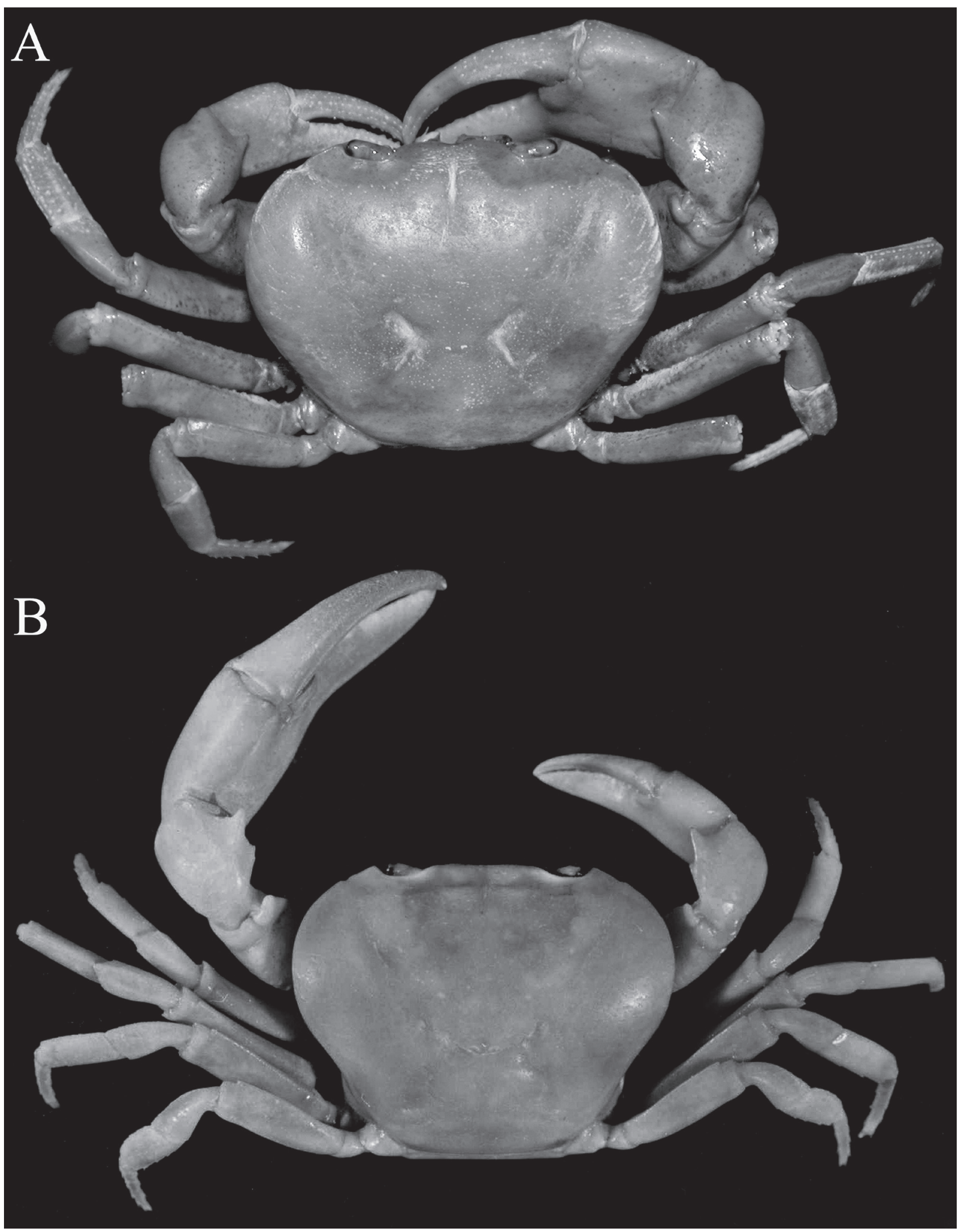

Figure 2. A, Sundathelphusa tuerkayi, new species, holotype, male $(34.7 \times 26.5 \mathrm{~mm})$ (SMF 1799a), Lombok, Indonesia. B, Sundathelphusa aruana (Roux, 1911), paralectotype, male $(27.9 \times 21.5 \mathrm{~mm})(\mathrm{NMB} 695 \mathrm{a})$, Aru Islands, Indonesia. 


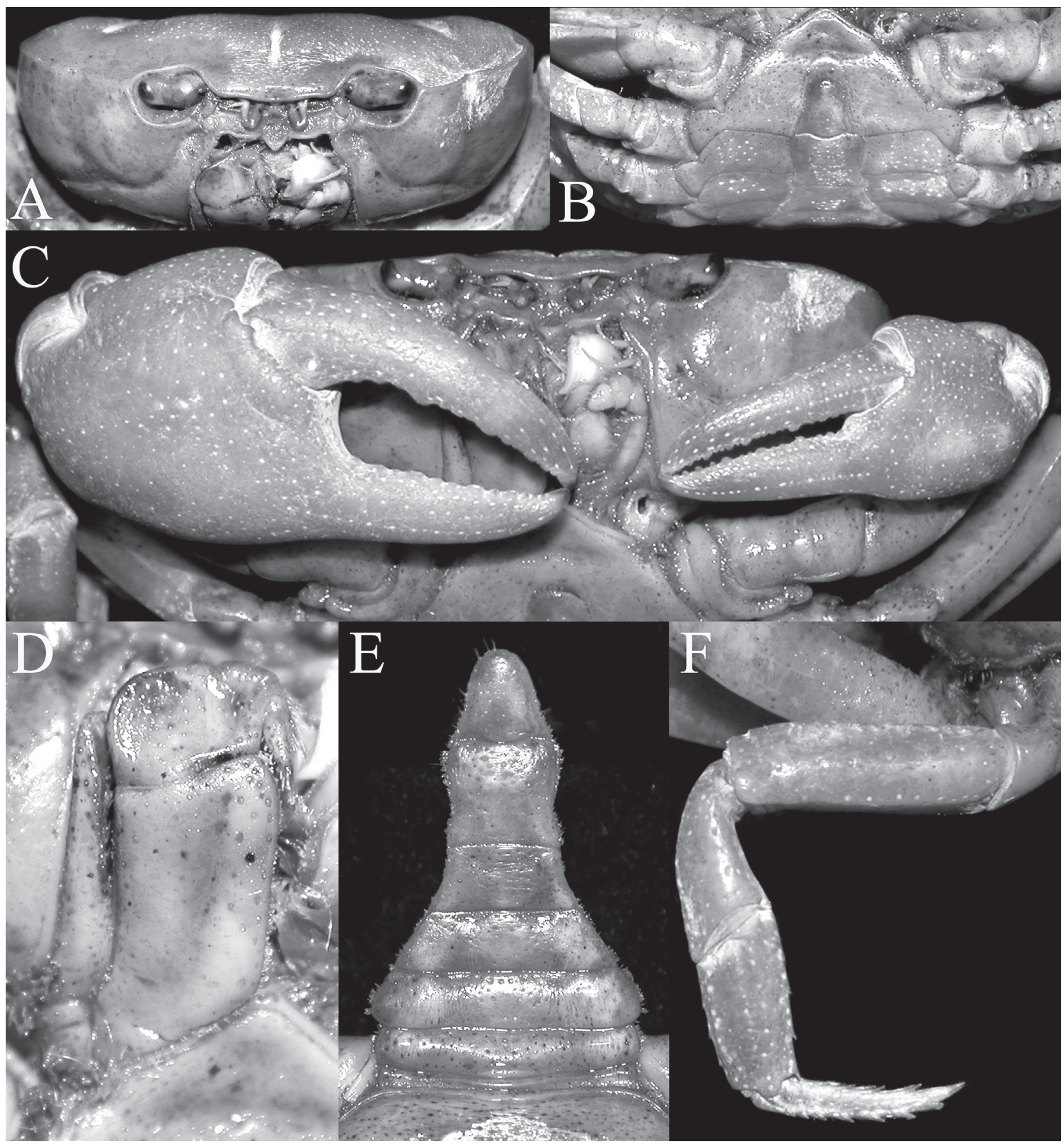

Figure 3. Sundathelphusa tuerkayi, new species, holotype, male $(34.7 \times 26.5 \mathrm{~mm})$ (SMF 1799a), Lombok, Indonesia. A, frontal view; B, anterior thoracic sternum and abdomen; C, chelipeds; D, right third maxilliped; E, abdomen; F, right fourth ambulatory leg.

posterior half more mottled and reticulate with uneven cream patches; dorsal surfaces of chelipeds orangebrown with patches of reddish-brown; ventral surface of chela palm and fixed finger yellow; dorsal surface of ambulatory legs cream with reddish-brown specks and patches; ventral surfaces pale yellow to cream (Fig. 1).

Etymology. The new species is named after our late friend and colleague, Michael Türkay, for his numerous contributions on taxonomy of decapod crustaceans. He 


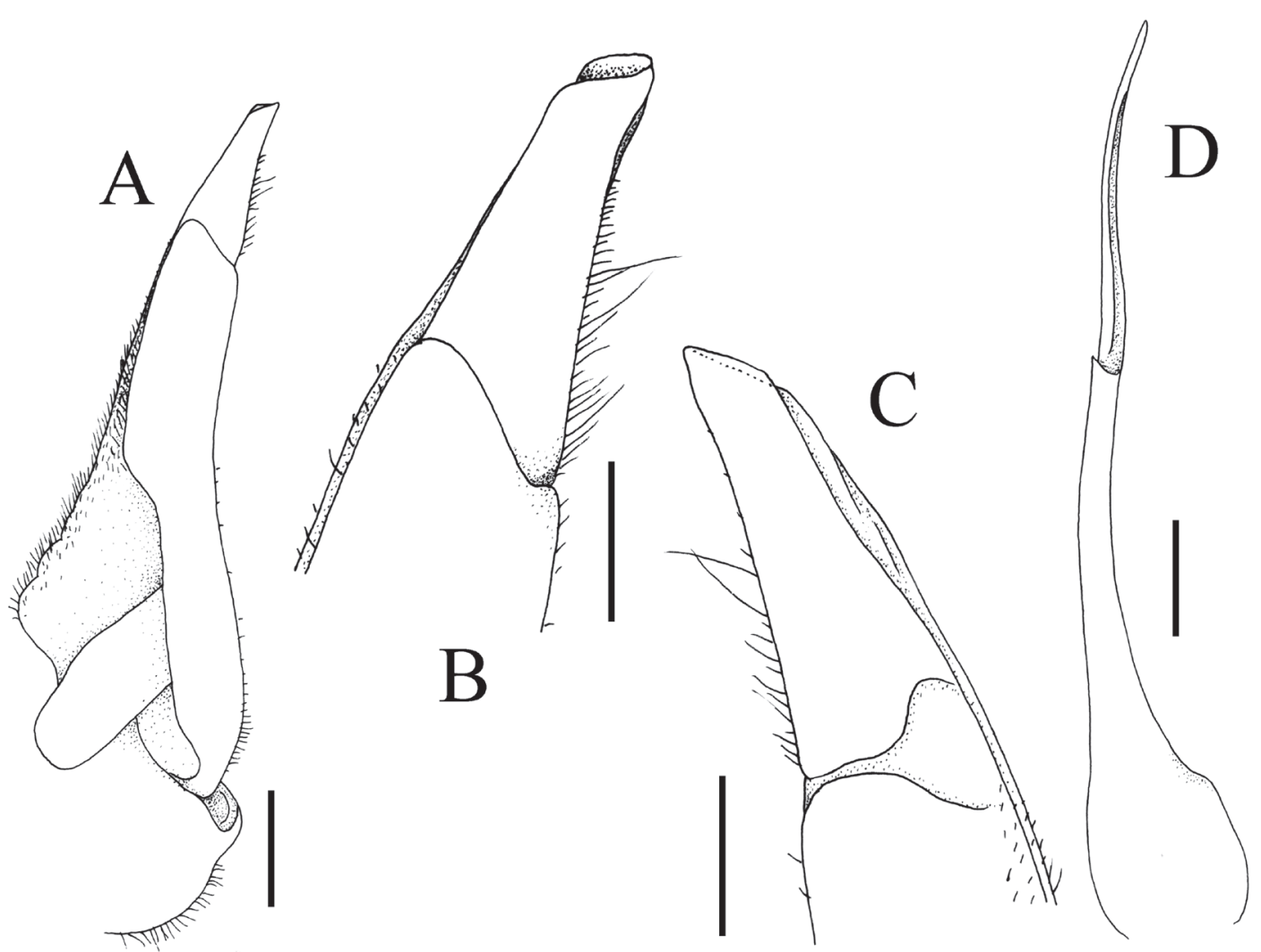

Figure 4. Sundathelphusa tuerkayi, new species, holotype, male $(34.7 \times 26.5 \mathrm{~mm})$ (SMF 1799a), Lombok, Indonesia. A, ventral view of left G1; B, ventral view of terminal segment of left G1; C, dorsal view of terminal segment of left G1; D, ventral view of left G2. Scales: A, D = $1.0 \mathrm{~mm} ; \mathrm{B}, \mathrm{C}=0.5 \mathrm{~mm}$.

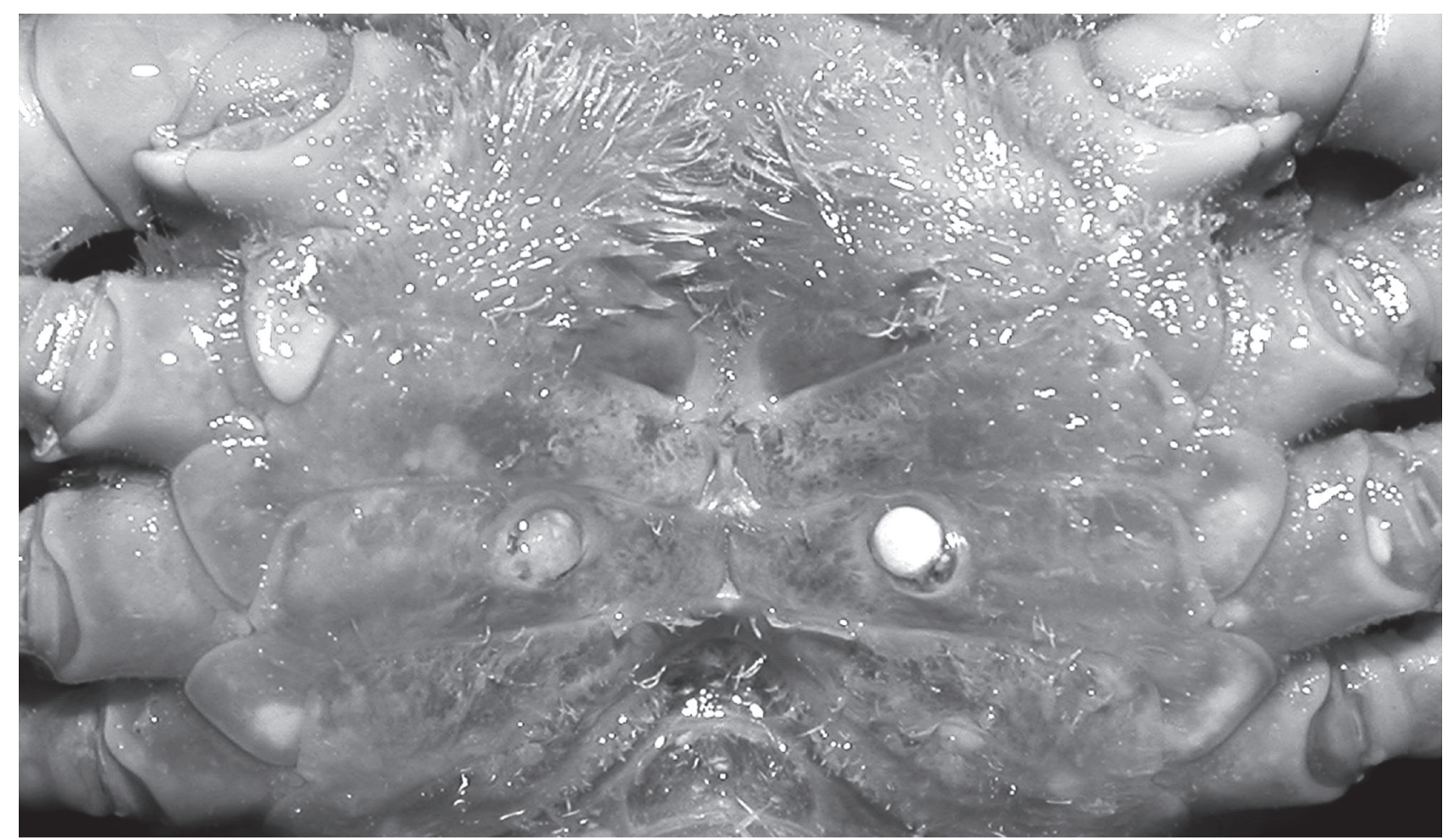

Figure 5. Sundathelphusa tuerkayi, new species, paratype, female $(38.0 \times 29.4 \mathrm{~mm})($ SMF 1800$)$, Lombok, Indonesia; thoracic sternum showing vulvae. 
was a wonderful host and always facilitated our visits to SMF with great enthusiasm - he will be sorely missed.

Distribution. The new species appears to be endemic to Lombok Island in central Indonesia, where it is presently known from Sembalun, Praya, Suranadi and
Lombok Barat, at altitudes ranging from about $200 \mathrm{~m}$ to just over $1000 \mathrm{~m}$.

Biological notes. All crabs collected near Suranadi were found in the dense vegetation fringing banks of a small stream, about two metres wide (with some
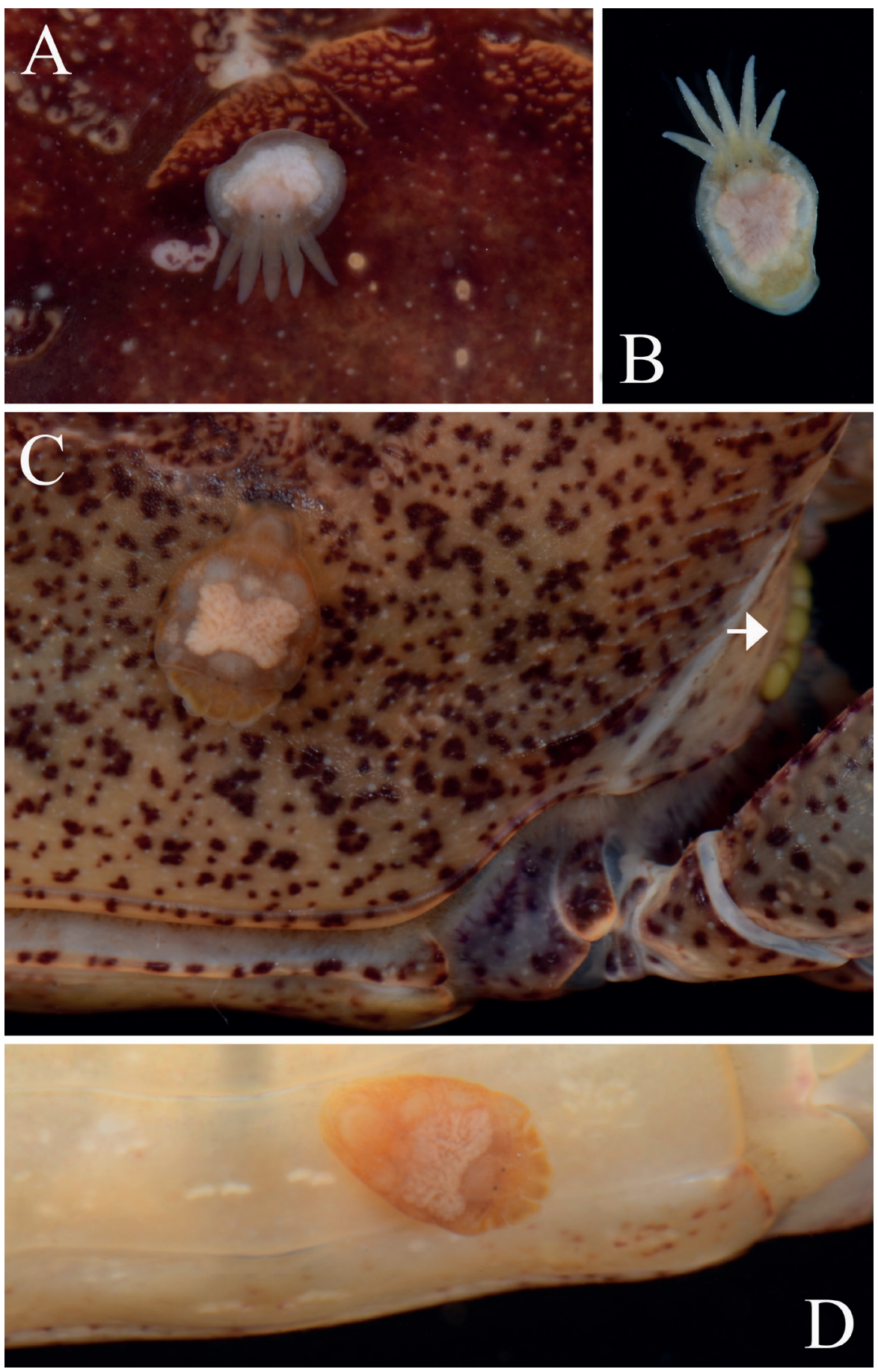

Figure 6. Symbiotic flatworm (Temnocephalida, possibly species of Temnosewellia Damborenea and Cannon, 2001) associated with Sundathelphusa tuerkayi, new species, in Lombok, Indonesia. A, flatworm in situ on carapace, with tentacles extended; B, flatworm in vitro; C, flatworm in situ on carapace, with tentacles retracted, arrow pointing to eggs attached to right branchiostegium (see also Fig. 1A); D, flatworm in situ on abdomen, with tentacles retracted. 
wider pool-like areas), with a weak to moderately strong current. Crabs from Lombok Barat were found hiding under rocks in a fairly large pool under a waterfall, about $0.2-0.5$ deep. An ectosymbiotic temnocephalid flatworm, possibly belonging to the genus Temnosewellia Damborenea and Cannon, 2001 (Platyhelminthes: Temnocephalida) characterised by the presence of five cephalic tentacles (Fig. 6), was found on at least three crab specimens. The flatworm attaches its conspicuously yellow-greenish eggs symmetrically to the posterior branchiostegal region of the cephalothorax, just above the coxae of the second and third ambulatory legs (Figs. 1A, 6C). The taxonomy and biology of this flatworm remain to be studied.

Remarks. Roux (1911: p. 91) described Potamon (Geotelphusa) aruanus based on numerous specimens from three localities in Kobroor in the Aru Islands: Seltoutti, Manoumbai and Sungei Kololobo. Bott (1970: p. 75) selected a male from Manoumbai as lectotype and a paralectotype male from Kololobo (Fig. 2B) was examined for the present study (see also Chia and $\mathrm{Ng}, 2006$ ). Comparisons of $S$. aruana with the material from Lombok herein described as $S$. tuerkayi, new species, makes it clear that two species are involved.

The external orbital tooth of S. tuerkayi, new species, is relatively wider (Figs. 1A, 2A) (this tooth being distinctly narrower in S. aruana, Fig. 2B; Chia and $\mathrm{Ng}$, 2006: fig. 42A); the antero- and posterolateral regions of the carapace are distinctly more rugose with the striae more prominent (Figs. 1A, 2A, 3A) (their surfaces being smoother and the striae rather low in S. aruana, Fig. 2B; Chia and Ng, 2006: fig. 42A); the epigastric cristae are situated distinctly anterior to the postorbital cristae (Figs. 1A, 2A, 3A) (the epigastric and postorbital cristae are more or less at the same level in S. aruana, Fig. 2B; Chia and Ng, 2006: fig. $42 \mathrm{~A})$; the meri of ambulatory legs are relatively longer and more slender (Figs. 1A, 3F) (they are relatively shorter and stouter in S. aruana, Fig. 2B); the dactyli of ambulatory legs are relatively longer (Figs. 1A, 2A, 3F) (they are relatively shorter in S. aruana, Fig. 2B; Chia and Ng, 2006: fig. 42A); the G1 is proportionately more slender, with the distal part of the subterminal segment noticeably narrower (Fig. 4A) (the G1 is proportionately stouter, with the distal part of the subterminal segment wider in S. aruana, cf. Chia and $\mathrm{Ng}$, 2006: fig. 43A, B); and finally, the terminal segment of the $\mathrm{G} 1$ is stouter, with the tip truncate (Fig. 4A-C) (the terminal segment being evenly conical, more slender and with a sharp tip in S. aruana, cf. Chia and Ng, 2006: fig. 43A-D). These differences are consistent in the good series of male specimens examined and are also valid for females when non-sexual characters are involved.

With regard to the other species of Sundathelphusa occurring in central Indonesia, S. tuerkayi, new species, differs from Sundathelphusa cassiope (De Man, 1902) from Sulawesi in having a relatively lower epibranchial tooth; the lower postorbital cristae; the relatively longer, more slender ambulatory legs; and the proportionately longer male abdominal somite 6; however, their G1 structures are superficially similar (De Man, 1902: pl. 20, fig. 18; Chia and $\mathrm{Ng}$, 2006: figs. 39A, 40); from Sundathelphusa minahassae (Schenkel, 1902), also from Sulawesi, by a more transversely ovate carapace, with the striae on the dorsal surfaces being less prominent; the relatively longer ambulatorylegs; and a more curved G1 (cf. Chia and Ng, 2006: figs. 39B, 41); and from Sundathelphusa rubra (Schenkel, 1902) from Sulawesi by the anterior parts of the carapace less prominently swollen; longer ambulatory legs; and in possessing a much longer $\mathrm{G} 1$ terminal segment, which is very short in S. rubra (cf. Chia and Ng, 2006: figs. 42B, 44).

\section{ACKNOWLEDGMENTS}

We thank Dwi Listyo Rahayu, Muhammad Firdaus, Idham Sumarto Pratama and other staff of the Indonesia Institute of Sciences (LIPI) in Pamenang, Lombok, Indonesia, for their kind assistance in the field and in the laboratory.

\section{REFERENCES}

Bott, R. 1969. Die Flusskrabben aus Asien und ihre Klassifikation (Crustacea, Decapoda). Senckenbergiana biologica, 50(5/6): 359-366.

Bott, R. 1970. Die Süsswasserkrabben von Europa, Asien, Australien und ihre Stammesgeschichte. Eine Revision der Potamoidea und Parathelphusoidea (Crustacea, Decapoda). Abhandlungen der Senckenbergischen Naturforschenden Gesellschaft, 526: 1-338, pls. 1-58.

Chia, O.K.S. and Ng, P.K.L. 2006. The freshwater crabs of Sulawesi, with descriptions of two new genera and four new species (Crustacea: Decapoda: Brachyura: Parathelphusidae). Raffles Bulletin of Zoology, 54(2): 381-428. 
Damborenea, C. and Cannon, L.R.G. 2001. On neotropical Temnocephala (Platyhelminthes). Journal of Natural History, 35(8): 1103-1118.

Man, J.G. de. 1902. Die von Herrn Professor Kükenthal in Indischen Archipel gesammelten Dekapoden und Stomatopoden. In: W. Kukenthal (ed.), Ergebnisse einer zoologischen Forschungsreise in den Molukken und Borneo. Abhandlungen der Senckenbergischen Naturforschenden Gesellschaft, 25: 467-929, pls. 19-27.

Ng, P.K.L. 1988. The freshwater crabs of Peninsular Malaysia and Singapore. Singapore, Department of Zoology, National University of Singapore, Shinglee Press, pp. i-viii, 1-156, plates 1-4.
Ng, P.K.L. 1997. On a new genus and four new species of freshwater crabs (Crustacea: Decapoda: Brachyura: Parathelphusidae) from Borneo and Java. Raffles Bulletin of Zoology, 45(1): 105-121.

Rathbun, M.J. 1904. Les crabes d'eau douce (Potamonidae). Nouvelles Archives du Muséum d'Histoire Naturelle, Paris (4)6: 225-312.

Roux, J. 1911. Nouvelles espèces de décapodes d'eau douce provenant de Papouasie. Notes from the Leyden Museum, 33: 81-106.

Schenkel, E. 1902. Beitrag zur Kenntnis der Dekapodenfauna von Celebes. Verhandlungen der Naturforschenden Gesellschaft in Basel, 13: 485-585, plates 7-13. 